\title{
The Folk Custom Projection of Bloodline Heritage of Ethnic Group-Inspection and Analysis of Gejia People's Music and Dance
}

\author{
Guo Zhenhua Yang Jun \\ College of Sports Science, Jishou University \\ Jishou, China \\ E-mail:jsdxgzh@126.com
}

\begin{abstract}
Gejia is an extremely rare minority ethnic group in China which remains to be identified. From the perspective of the development of ethnic groups, the research pays special attention to the inheritance and protection of special small ethnic folk sports culture. Using the research methods, such as anthropological fieldwork, ethnic Literature and so on, Gejia's Folk music and dance has been excavated and sorted. The research results show: Gejia is the community that gradually formed through the history baptism. Cultural identity is the link to maintain the ethnic community. Along with the progress of history, the cultural identity has been strengthened, so as to so as to constitute gejia people's family bloodline. During the course of thousands of years of civilization development, Gejia people seek truth from facts and create the colorful culture of music and dance, showing strong vitality, so as to provide a strong spiritual power for the development and continuation of ethnic group, which is the spiritual place that the ethnic group goes through different times and maintain identity of subject. Gejia's music and dance with Gejia's unique style and features stands on the Chinese nation. With strong vitality, it deeply roots in Gejia people's heart, and adds the brightness for the Chinese nation's sports culture.
\end{abstract}

Keywords-Gejia; Folk Sports Culture; Ethnic Group; Folk Custom

Cultural events are gradually formed and passed from generation to generation in practice. Gejia home has a long history of folk traditional ethnic heritage, rich and colorful folk culture from generation to generation. These folk customs not only give people's life adds a lot of color, increase the national cohesion, but also has the role of ethnic groups in blood heritage. Among them, music and dance in the process of blood groups heritage acts as a important role, such as the formation of imparting knowledge and skills, to a historical event or historical figures public memory, villages, the development of interpretation. And the dance as a kind of cultural phenomenon scattered in the Gejia family of colorful folk activities, meet in family groups living needs of Gejia, Gejia family daily life service, inheritance of the nation's blood.

\section{BOW DANCE AND ETHNIC IDENTITY}

Dance of the bow and arrow is Gejia family cherishes the memory of ancestors, by Gejia family favorite dance, this dance is not only effectively exercise fitness, but also a good inheritance of the history and culture of the ethnic groups. Hou Yi's family claimed to be descendants of the hunting people. (Qing Dynasty) "Annals of Guizhou" contains: "the customs entry, with Gejia for students. [1] "To change into a living" means to hunt for a living. The historical records recorded in "Gejia pocket like game, or" Miao "into the game Lo que [2]" etc. For a Gejia hunting skill, the ancient poem in praise: "the competition must make Gejia bag [3]." As the saying goes "Gejia men three treasures, bows, Lusheng and sword". The family can rely on Gejia hunting students earning interest with the indissoluble bound with bows and arrows. A man regarded as life Gejia bow, bow to worship to. Gejia family worship bows, arrows with pride, reflected in all aspects of life. Gejia ancestral drum the most important festival next ha Rong to put a bow to the guardian. The shrine honors on the bow [4], graves gravestone also engraved with the bow. Across ethnic groups are the bow and arrow as a sacred worship, bow and arrow is Gejia family of soul, Gejia family roots, Gejia home in the hearts of the totem and struggle with the natural weapons. In addition to the Gejia home, in our country, no which minority communities of the bow and arrow so devout, so Gejia family by some has long been engaged in ethnic studies scholars known as the "bow and arrow" tribe. From the Gejia bow dance home, can deeply feel the primitive society early Gejia family and beast with hardship. Human in beast wildfowl sway in the initial stage, no defense weapons and fell beast skills and the skills, is difficult to survive. According to the elderly, invented the bow and arrow not to create, but in order to defense and attack. "Huainanzi" records, the legendary hero who shot the Suns with bow and arrow is the red bow and white arrow in Gejia home shrine hanging over the bow and arrow and red and white arrows. Bow with peach branches bent, 5 bamboo arrows hung in the bowstring. Gejia family love arrow is also reflected in their clothing and daily life: Gejia woman head red disc in the cone of the silver hairpin like Houyi the arrow root, men's clothes also batik with bow and arrow graphics, apart from labor, Gejia family is the shooting as a recreational activity, to express them of the bow and arrow of reverence and worship. The winter solstice, Gejia family will go into the mountains nearby, in groups of three and four, hunting, is one to ten days and a half months [5].

\section{Migration DANCE AND ETHNIC ORIGIN IDENTIFICATION}

Folk custom, as a kind of intangible cultural resources, has a long history in the folk. In the long history, it has produced many cultural symbols, and has become an endless resource of folk custom. It is in imperceptible in succession and development, and then with the passage of 
time and constantly enriches and continues. Ancestors of the difficult development and migration history as a group of memory, is often deliberately rendering and stressed to strengthen their ethnic identity. The Gejia family has a long history and many traces of the ancient clan system are still maintained in this group. And the family believed in their fathers, for generations to believe that they were the ancestors of the house of the soul, the symbol of their ancestors. So the worship of ancestral drum has become the spiritual pillar of the family, the emotional connection with the internal social organization, the unity of the inner sense of ethnic groups. The Gejia family worship ceremony is called "Kazakhstan Rong"[6], and it is grave and warm. Since it is a form of worship, there must be the expression of worship. Gejia migration history has become the past, but their "word" migration today is still in the everlasting. In some of the larger villages, the annual winter solstice or lunar July 16 day, every household to focus to store the ancestral drum family worship ancestral drum, the Yin and Yang of two-line tissue but also in front of the ancestral drum blow pipes and drums, and chanting a day and a night "migration of words", to strengthen the education of family history. At the same time, this opportunity to transmit to future generations "migration" Lusheng, and music. Because of the word "home" Gejia migration is usually not sing and teach, is permitted only in the memorial day once a year. The migration word "singing is a singer, all round close, sonorous singing, tone of desolation, sings some tragic end, people often tears, scene moved. A "migration" often takes three hours to complete. In addition to read "the word" migration, migration performance of Gejia family Lusheng dance is one of the essential. For a good start of the games, Lusheng team to practice skills more than first Lusheng songs and remember spectrum, learn each song of dance moves, from playing to dance moves, even blowing jump posture to accord with the requirement, heavy workload, particularly hard. Heavier Hing town Fengxiang stockade Lusheng migration in the dance can be learned, Gejia family of the ethnic homelands have deep historical memory, this memory traces and expression of the ethnic origin of the ethnic groups, ethnic roots of emotional arousal is they of the racial and ethnic identity of the deepest expression.

\section{LUSHENG DANCE AND SPIRITUAL CRADLE OF GEJIA GROUP}

Ethnic culture, as spiritual activities and physical activities of common rules, must be a history of the nation has been able to endless stretches of Inner Mechanism and blood. Gejia home after a long history of construction absorbed a lot of foreign outstanding cultural essence, forming a splendid sight Lusheng dance culture. Lusheng dance as a cultural phenomenon embodied Gejia home of their historical experience and knowledge of the world is the cradle of the Gejia family spirit. It gave birth to nourish the Gejia family together fighting spirit, common ideals and common feelings and values and is the common spiritual homeland Gejia family. A nation, if blood heritage is the body, the soul is a heritage context. Lusheng Dance is the soul of the Gejia family going, its river of civilization shining treasures [7].
Lusheng dance is most loved in the Gejia family, the Gejia family weddings and marriage, and Lusheng dance can be seen in happy festivals. Gejia house Lusheng dance colorful, lively. Gejia home side while blowing Lusheng hand can dance, and dance to a variety of actions, such as monkeys and roll, rock eagle wings, under thrush nest like. According to legend, this dance in ancient times, people will already have Gejia pocket jump, historical witness Gejia family. According to incomplete statistics, there are over 250 kinds of Lusheng dance jumps. Lusheng civil division passes by saying that jump three days and nights of non-repetition. Lusheng is a race of ancient Gejia poem, a song Lusheng is a family of ancient Gejia movement, and a Lusheng dance is a dance poem Gejia family. These dances are Gejia Gejia ancestral family in accordance with which the living environment and honest, simple, elegant character and a unique national style and carefully created, Gejia tribe is spiritual food, the spiritual pillar and spiritual sustenance. This dance can be spread in Gejia home has been loved by the people, which received the application, the value is here. Lusheng dance can say is Gejia family progenitor (ancestor), the root of the Gejia family of "ethnic roots" Gejia family soul (national soul), Gejia family life (life).

\section{RITES OF BIRTH AND “TO ZHU MU” DANCING CEREMONY}

Custom has inheritance, universality and stability of model properties, and derives a series of other attributes, that only when some group activities become repeatedly in the same way, it was possible to customs handed down from generation to generation. "To Zhu $\mathrm{Mu}^{\prime}$ belongs to the birth of rites, and rites of life in the Gejia Tim gave birth to their first child after the celebration, with distinctive national characteristics. "To Zhu Mu" in Gejia home many Rites has an important position, implication and reveals the nation's survival philosophy, reflecting the people dyad heir reproduction attention, incense constantly, prosperity of the family of the symbol. It is the blessing of the newborn, is a kind of ancient heritage, but also a big song and dance festival. In the Gejia, birth is a thing that people celebrate, put up a pageantry to make arrangements for the event, event. From Fengxiang stockade Liao family "" $\mathrm{Ka}$ "words" "ancestor fair to blame the barbarous people", "Gong $\mathrm{Zu}$ complain that white people of Han,", "sword intersecting back", "the knife relative" can deeply feel the Gejia home of this ancient nation had to bear the hardship. In order to multiply blood, we must continue to bear. "Want to" song and dance ceremony is in the strong sense of clan and a strong sense of national consciousness. "To $\mathrm{Zhu} \mathrm{Mu}$ ceremony to dance a grass horse dance, dance bench, a symbol of family, thrive in the dance, the characteristics of primordial germ worship is very prominent. Grass horse dance is composed of several women riding a horse dance with straw. This dance is women hip and groin are jostled, in imitation of men and women make love posture, the mouth also kept to invoke the climax when the excitement of the "Yo" and "Yo" sound, joyous dripping to advance and retreat freely dance. Dance to the emotional place, and some women also used wooden 
sticks or bamboo broom and other items between the legs to act as a male genital, dancing in a carnival. Bench dance and vigorous, when one pair of stool, also contains the meaning of copulation conceived. The action is very original, the whole scene lively [8].

\section{ANCIENT MARRIAGE CUSTOMS AND "STEPPING DANCE"}

Folk custom is a kind of culture, which is the most appropriate body and mind and life of the people, and it is a social science. This is not only because of the folklore in the lives of the majority of people widely infiltrated, and in society at all levels, but also reflects a group of spiritual and psychological. Folk custom not only in the festival, the popular unwritten life style in life there are a lot of. In the customs of our colorful culture, ancient magical Gejia home marriage with its unique form and rich cultural connotation become rare wonderful culture. Marriage and family, Gejia is mainly through the "step", "bron", "March climbed the slope day" and other activities to young men and women with each other to promote the understanding, and enhance mutual feelings. Finally, it is the conclusion of marriage. "Brune" means falling in love, "Aaron Abu Jiayu Gejia". This activity is usually in the first month of the second, fourth, the fifteenth day of the first lunar month, 16 or the first two days of February, whenever the festival, young men and women gathered in the village, intersection, hillside village foot (Dance), pick your Mr. Right. Gejia in March climbed the slope day and fix a time sequential, with yellow float slope a rallying point for the largest, for a period of three days. Dressed in costumes of the Miao girls, the first crown silver cap, wrapped around a row of silver belt, with Lusheng rise and these girls dance in a happy mood. The home of young men and women dressed in Gejia, clothing, mountain song, unprecedented. There are two kinds of rituals for marriage. Common rite, to escort women requirements is very high, in addition to its good character, and when parents are still alive, children taste. It must be good at both singing and dancing won bear the responsibility. During the meeting, Li Song will become a variety of content. On the poor, do not send out the bride. "Marry" the ancient wedding ceremony, pro, in addition to select two porters and two women [9]. Also please three potential singing and dancing men. At the woman's home, they sing and dance all the night, lively and noisy day. "Dear step dance" in a festival on life dear hop dance scene. Dear on the dance, dance and you step on my beat, you before me, to and fro, warm and cheerful, humorous scenes. In the "Lusheng Festival on dear" activities, and be concerned with love and romance is not subject to any formal etiquette. It is true, "it is hard to express the deep love, but only the twilight is a reminder."

\section{VI. .ENHANCEMENT OF FUNERALS AND ETHNIC IDENTITY}

As an important part of the culture, funeral is an important content of social etiquette, which is the most complex part of the culture, which embodies a nation's character, psychological quality and thought, and then reveals the history of the formation and development of various ethnic groups. The funeral custom Gejia affected by the Han nationality, but retains some characteristics and the legacy of Gejia. Gejia funeral home has five characteristics: one is to send "reformed"; the second is chisel tooth; the third is "open"; fourth, with bamboo funerary; five is the use of mourner dog. It is worth mentioning that, if the University who died, the funeral does better than average grand and warm. A Gejia home university called "ang to", meaning that the chief Lusheng division, highly respected Gejia. In Gejia group, university life to others' sacrifice, happy things welcome visitors and see them off, and make arrangements for the funeral. After his death, his funeral held for at least three days, this is all his disciples and relatives of his special reward. In these three days, his disciples, brothers and relatives will round the clock for his dance. Come to participate in the ritual of family and friends, wearing must be like a grand festival [10].

\section{VII. .CONCLUSION}

Comrade Hu Jintao has proposed in the report of the eighteenth People's Congress that culture is the nation's blood and the spiritual home of the people. Gejia is ethnic community through baptism evolving history, cultural identity is to maintain this ethnic community ties. With the course of history, this cultural identity continues to be strengthened, so as to constitute a blood Gejia. In the course of thousands of years of civilization, the Gejia, selfimprovement, to create a variety of music and dance culture, showing strong vitality for the development of the Gejia group and continues to provide a strong spiritual power, is the nation through different times and maintain their own identity to the spiritual body home. Gejia house music and dance in a unique style and features Gejia house stands in the nation among with strong vitality, deeply rooted in the heart of the Gejia, adding color to the sports culture of the Chinese nation.

\section{ACKNOWLEDGMENT}

Hunan Provincial Key Scientific Projects (15A154) ; State General Administration of sport open-end funds key research base of national sports topics (14jdzb023).

\section{REFERENCES}

[1] Guizhou Provincial Institute of Cultural and History Research Guizhou Annals. Records of Local People [M]. Guiyang: Guizhou People's Press, 2008:250

[2] Gu Yongji. Yunnan-Guizhou Annals [M]. Guiyang: Guizhou People's Press, 2008: 391.

[3] (Qing) Huang Zhaizhong, etc. (Daoguang) Gazetteer of Dading Mansion [M]. Etched Edition of $29^{\text {th }}$ Year in Daoguang Period.

[4] Lei Qinglan.From Ha Rong Festival Research the development of tourism of Fexiang village at huang ping in guizhou [J]. The Silk Road. 2010(12):50.

[5] Liu Liguo, XU Ye.. On the Martial Characteristics of Gejia's From the perspective of Ethnic Identification [J. Journal of Kaili University, 2013 (10):51

[6] Li Zhiwen.The symbol structure of rite Ha Rong of Gejia [J].Journal of Original Ecological National Culture,2012(4):114.

[7] Gao Guozhang.The history and customs of gejia[J]. Periodicals of Guizhou Culture and History,1990(3):124-128.

[8] liu Biqiang. The clothes of Gejia[J]. The Research of Culture and Art,1996. (3):79.

[9] Li Jiwen. Socia 1Memory and Ethnic Identification of Gejia People $[\mathrm{J}]$. Journal of Hubei University for Nationalities (Philosophy and Social Sciences), 2010 (5):25-29.

[10] Li Jiwen. On Ethnic Group Identity of Gejia People of Cultural Expression [J]. Qinghai National Research,2008 (10):20-24 